\title{
Effect of active immunization against oestradiol in developing ram lambs on plasma gonadotrophin and testosterone concentrations, time of onset of puberty and testicular blood flow
}

\author{
D. Auclair, S. F. Sowerbutts and B. P. Setchell \\ Department of Animal Sciences, Waite Agricultural Research Institute, University of Adelaide, \\ Glen Osmond, South Australia, 5064
}

\begin{abstract}
Merino ram lambs were actively immunized against oestradiol-6 (o-carboxy methyl) oxime-BSA conjugate at 14 weeks of age and received a booster injection 4 weeks later. This treatment led to an increase in plasma concentrations of gonadotrophin and tended to enhance the increase in testicular volume until 26 weeks of age; however, testis size and mass at time of castration (30 weeks of age) were similar to values in BSA-immunized lambs. Detrimental effects were observed in some oestradiol-immunized ram lambs, for example a steep decline in testicular volume towards the end of the experiment, the presence of large vacuoles within the seminiferous epithelium and, in one lamb, few germ cells at 30 weeks of age. Testicular blood plasma flow was significantly reduced in oestradiol-immunized lambs $(P<0.01)$. The steroidogenic function of the testis was markedly enhanced in oestradiol-immunized lambs as reflected by high plasma concentrations of testosterone measured at 22, 26 and 30 weeks of age and by high testosterone production calculated from blood flow and venous-arterial differences at 30 weeks of age. Nevertheless, total live mass gain over the 16 week study was not increased in oestradiol-immunized lambs. Testicular biopsies were taken at 22 and 26 weeks of age in half of the lambs in each treatment group. Testicular volume measured at castration was decreased in control lambs in which biopsies were taken $(P<0.05)$, and plasma concentrations of testosterone measured at 30 weeks of age were significantly lower in oestradiol-immunized lambs in which biopsies were taken $(P<0.02)$ compared with lambs in which no biopsy had been taken. It is concluded that active immunization against oestradiol in ram lambs does not advance the time of onset of puberty and does not confer any reproductive or maturational advantages.
\end{abstract}

\section{Introduction}

Before puberty, the hypothalamic-pituitary axis is extremely sensitive to inhibition by gonadal steroids, resulting in low tonic LH and FSH secretion. As puberty proceeds, there is a decrease in responsiveness to the inhibitory actions of steroids, resulting in increased gonadotrophin secretion, which is sufficient to initiate reproductive activity. This change in responsiveness, known as the 'gonadostat', is particulary apparent in male rats (Ramirez, 1973) and male sheep (Olster and Foster, 1986, 1988). In rams, oestradiol can provide potent negative feedback signals to the hypothalamic-pituitary axis under physiological conditions (Schanbacher, 1979; Schanbacher et al., 1984, 1987; Sanford, 1985, 1987a, b; Monet-Kuntz et al., 1988). Furthermore, oestradiol can inhibit testicular androgen production by affecting the metabolism of interstitial cells of rats (Hsueh et al., 1978; Brinkmann et al., 1980; Kalla et al., 1980; Moger, 1980; van der Molen et al., 1981; Aquilano and Dufau, 1983; Ronco et al., 1988), and men (Daehlin et al., 1985).

Revised manuscript received January 1995.
Oestrogen receptors have been identified in the hypothalamus (Pelletier and Caraty, 1981; Pelletier, 1982) and pituitary (Thieulant and Pelletier, 1979, 1985) of rams, but have not yet been identified or characterized in the testis. In rats, large amounts of oestrogen receptors have been found in purified Leydig cells, but there is still controversy concerning the presence of oestrogen receptors in Sertoli cells, and oestrogen receptors have not been identified in germinal cells (Brinkmann et al., 1972; Van Beurden-Lamers et al., 1974; Mulder et al., 1974; de Boer et al., 1976; Tsai-Morris et al., 1985).

Considering these lines of evidence, oestradiol could be regarded as a potent steroid that can restrain the maturational process associated with puberty in males. Land et al. (1981) found that the rate of growth of the testes increased in Merino lambs that had been passively immunized against oestrogens (between 14 and 26 weeks of age), but no response was observed by Jenkins et al. (1986) using a similar approach in younger crossbred lambs (between 2 and 16 weeks of age). The use of active immunization against oestradiol, a longer-term approach involving continuous production of antibodies, has not yet been tested in developing ram lambs. In comparison 
with passive immunization, active immunization eliminates all concerns about determining the amount of exogenous antibodies required to neutralize the hormone efficiently, and about the possibility that the recipient will mount an effective antibody-mediated clearance of exogenous antibodies (Nieschlag and Wickings, 1978).

Since the active immunization approach offers many advantages over passive immunization, we have explored the possibility of advancing the time of onset of puberty in Merino ram lambs by active immunization against oestradiol. An additional objective of this study was to evaluate the effect of biopsy sampling on testicular development.

\section{Materials and Methods}

\section{Animals}

Seventeen Merino ram lambs, born at the beginning of June, were kept outdoors with their mothers until weaning at 12 weeks of age, and were then transferred to a room with controlled light ( $12 \mathrm{~h}$ light:12 $\mathrm{h}$ dark). This lighting regimen was chosen because it was reported that ram lambs interpret this constant cycle as short days (Klindt ef al., 1985). The lambs were initially fed twice a day with commercial sheep pellets

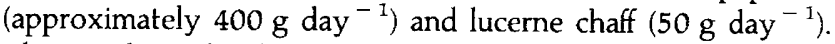
The number of pellets was increased throughout the experiment to achieve an average live mass gain of $120 \mathrm{~g}^{\text {day }}{ }^{-1}$. Pubertal development was studied intensively between 14 and 30 weeks of age. Variables assessed each week included live mass and testicular volume. Assuming that the testis is a prolate spheroid, testicular volume was calculated according to the formula $1 / 6 \pi a^{2} b$ (where $a=$ largest width and $b=$ length of the testis) (Setchell and Waites, 1964).

\section{Immunization procedure}

At 14 weeks of age, eight lambs received a primary injection of oestradiol-6(o-carboxymethyl)oxime-BSA conjugate (molar ratio of steroid to protein was 19:1) (Sigma Chemcial Co., St Louis, MO) in Freund's complete adjuvant (FCA), (Commmonwealth Serum Laboratories, Melbourne) while nine lambs (controls) were teated with BSA in FCA. All lambs received a booster injection 4 weeks later using Freund's incomplete adjuvant instead of FCA. The immunogen, $1 \mathrm{mg}$ antigen emulsified in $2 \mathrm{ml}$ saline:adjuvant ( $1: \mathrm{I} \mathrm{v}: \mathrm{v})$, was injected into each lamb at two s.c. and/or i.d. sites under each fore and hind limb.

\section{Biopsy procedure}

Testicular biopsies were taken from four controls and four immunized lambs at 22 weeks (left testis) and 26 weeks (right testis) of age. For practical reasons, the heaviest lambs were selected for this procedure. Except for a few modifications mentioned below, the technique performed was essentially that described by Lunstra and Echternkamp (1988). The ram lambs were tranquillized with xylazine $2 \%$ (Rompum: Bayer Australia Ltd, Botany, NSW) and the subcutaneous tissues around the spermatic cord were infiltrated with $5 \mathrm{ml}$ lignocaine $2 \%$ (lidocaine $\mathrm{HCl}$ : Delta Veterinary Laboratories Pty Ltd, Hornsby, NSW). A small triangular incision (approximately $5 \mathrm{~mm} \times 5 \mathrm{~mm} \times 5 \mathrm{~mm}$ ) was made into the tunica albuginea (extreme care was taken to avoid severing blood vessels in the tunica vasculosa layer of the capsule), and the protruding testicular tissue with the tunica albuginea was removed and immediately placed in Bouin's solution. The tunica albuginea, tunica vaginalis and skin were sutured separately using catgut. After surgery, rams were given an i.m. injection of $3 \mathrm{ml}$ of the penicillin preparation.

\section{Antibody titre and specificity}

The titre was determined by incubating $100 \mu$ of various dilutions of plasma (from 1:10 to $1: 20000$ ) with $100 \mu \mathrm{l}$ of $\left(2,4,6,7,16,17-{ }^{3} \mathrm{H}[N]\right)$ oestradiol $\left(\left[{ }^{3} \mathrm{H}\right]\right.$ oestradiol: about $18 \mathrm{pg}$ per $100 \mu \mathrm{l})$ and $100 \mu \mathrm{l}$ of $0.05 \mathrm{~mol} \mathrm{PBS} l^{-1}$ plus $0.2 \%(\mathrm{w} / \mathrm{v})$ gelatin overnight at $4^{\circ} \mathrm{C}$. Free and bound hormone were separated with $500 \mu \mathrm{l}$ dextran-coated charcoal $(25 \mathrm{mg}$ dextran T70 and $250 \mathrm{mg}$ Norit A charcoal in $100 \mathrm{ml}$ PBS) for $15 \mathrm{~min}$ at $4^{\circ} \mathrm{C}$. The tubes were then centrifuged at $1000 \mathrm{~g}$ for $15 \mathrm{~min}$; the supernatant was transferred to polyethylene scintillation vials; and the radioactivity was counted. The titre was defined as that dilution binding $50 \%$ of the radiolabelled oestradiol.

Plasma samples from each oestrogen immunized lamb, collected at 30 weeks of age, were tested for crossreactivity. Specificity was examined by incubating diluted plasma (dilution binding $50 \%$ of $\left[{ }^{3} \mathrm{H}\right]$ oestradiol) with $\left[{ }^{3} \mathrm{H}\right]$ oestradiol in the presence or absence of graded doses of nonlabelled oestradiol, oestrone, oestrone sulfate, testosterone, dihydrotestosterone, or androstenedione $\left(0-1000 \mathrm{pg} \mathrm{ml}^{-1}\right)$. The relative inhibitory activity of each steroid for the antiserum was calculated from the ratio of the mass of oestradiol required to displace $50 \%$ of $\left[{ }^{3} \mathrm{H}\right]$ oestradiol to the mass of the crossreacting steroid required to displace the same fraction of $\left.{ }^{3} \mathrm{H}\right]$ oestradiol.

\section{Blood collection and hormone assays}

The lambs were bled intensively from an indwelling polyethylene cannula in the jugular vein (every $20 \mathrm{~min}$ for $6 \mathrm{~h}$ ) at 14, 22, 26 and 30 weeks of age. Mean hormone concentrations were determined by assaying a plasma pool representing the $6 \mathrm{~h}$ sampling period. Plasma LH, FSH and prolactin concentrations were measured using a double-antibody radioimmunoassay procedure (D'Occhio and Setchell, 1984), using materials and protocols supplied by the NIDDK (Torrance, CA). The reference standards used were: NIADDK-oLH-25, NIDDKoFSH-RP-I, NIDDK-oPRL-I-2 and the tracers used were: ${ }^{125}$ Ilabelled NIADDK-oLH-I-3, ${ }^{125}$ I-labelled NIDDK-oFSH-I-I and ${ }^{125}$ I-labelled NIDDK-oPRL-I-2. The following antisera were used: NIADDK-anti-oLH-I, at dilution 1:2000 000; NIDDKanti-oFSH-1, at dilution 1:80 000 and NIDDK-anti-oPRL-2, at dilution 1:600 000. The sensitivity of these assays was $0.2 \mu \mathrm{g}$ $1^{-1}, 0.2 \mu \mathrm{g}^{-1}$ and $1.0 \mu \mathrm{g} \mathrm{l}^{-1}$ for LH, FSH and prolactin, respectively. The intra-assay coefficients of variation were $5.5 \%, 8.4 \%$ and $9.3 \%$ for $\mathrm{LH}, \mathrm{FSH}$ and prolactin, respectively. The interassay coefficients of variation were $13.4 \%, 13.9 \%$ and $15.0 \%$ for $\mathrm{LH}, \mathrm{FSH}$ and prolactin, respectively. Testosterone 
concentrations were determined by extraction radioimmunoassay (using toluene:hexane; $2: 1 \mathrm{v}: \mathrm{v}$ ) as previously described and validated by D'Occhio and Brooks (1983). The testosterone antiserum (no. 457) was a gift from R. I. Cox (Hormone Assay Development Group, CSIRO, Division of Animal Production, Prospect, NSW). The crossreactivity of this antiserum is $98 \%$ with dihydrotestosterone, $47 \%$ with 4 -androsten-3 $3,17 \beta$-diol, $4.7 \%$ with androstenedione, $3.6 \%$ with 4 -androsten- $17 \beta$, 19 diol-3-one, and less than $1 \%$ with other steroids. The sensitivity of this assay was $0.2 \mathrm{nmol} \mathrm{l}^{-1}$ and the intra- and interassay coefficients of variation were $5.2 \%$ and $17.1 \%$, respectively.

\section{Characterization of $L H$ profiles}

The LH profiles were analysed for pulses using a computer algorithm program developed by P. L. Taylor (MRC Reproductive Biology Unit, Edinburgh) for the Apple Mackintosh microcomputer (Munro: Elsevier-BIOSOFT, Cambridge, UK). The analyses were carried out as described by Martin et al. (1987) using the following parameters. The $G$ parameters (the number of standard deviations by which a peak must exceed the baseline in order to be accepted) were 3.98, 2.40, 1.68, 1.24 and 0.93 for GI-G5, these are the requirement for pulses composed of one to five samples that exceed the baseline, respectively. The Baxter parameters, based on the intra-assay variations in replicate determinations (six per sample) of quality control plasma pools at different $\mathrm{LH}$ concentrations were $0.09129,0.01235$ and 0.01010 for $b_{1}, b_{2}$ and $b_{3}$, respectively. Nadirs (minimal LH concentration up to $60 \mathrm{~min}$ before the peak of a pulse), pulse intervals and pulse amplitudes (difference between pulse peak and preceding nadir) were calculated for each pulse and mean values for each profile were used in the analysis of treatment effects.

\section{Total testicular blood plasma flow, testosterone production and response to $h C G$ challenge}

Before castration, three controls and three oestrogenimmunized ram lambs were anaesthetized using sodium pentobarbitone (Nembutal, Abbott: Ceva Chemicals Australia Pty Ltd, Hornsby, NSW). The lambs were kept in a supine position during the procedure. Testicular blood flow was measured by p-amino-hippuric acid infusion, essentially as described by Laurie and Setchell (1978), Chandrasekhar et al. (1985a), Setchell et al. (1991a) and Mieusset et al. (1992). Cannulae were positioned in one testicular vein (under the caput epididymis) and one internal spermatic vein. A $2 \%(\mathrm{w} / \mathrm{v})$ solution of $p$-amino-hippuric acid was then infused at the rate of $100 \mu \mathrm{l}$ $\min ^{-1}$ into the testicular vein using a peristaltic pump (Minipulse 2 Gibson, Villiers). Blood samples were withdrawn from the internal spermatic and jugular veins at $10 \mathrm{~min}$

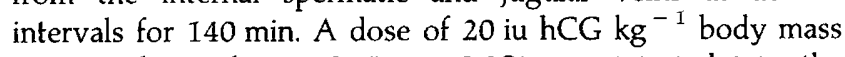
(Sigma Chemical Co., St Louis, MO) was injected into the jugular vein $40 \mathrm{~min}$ after the start of blood sampling. This dose was chosen because it can produce a maximal short-term testosterone response in ram lambs (Chandrasekhar et al., 1985b). The method of Kaland and MacArthur (1950) was used to determine $p$-amino-hippuric acid concentration in plasma samples. Testosterone production (defined as the product of total testicular blood plasma flow and the difference in testosterone concentration between each internal spermatic vein and the jugular vein) was also calculated.

\section{Measurements after castration}

The ram lambs were castrated at 30 weeks of age, except for the two lightest lambs (one control and one immunized animal which were castrated at 34 weeks of age). The testis and the epididymis were not separated from one another, but weighed together, and then perfused, via the testicular artery, with saline followed by $2 \%(\mathrm{w} / \mathrm{v})$ glutaraldehyde in $0.1 \mathrm{~mol}$ cacodylate buffer $\mathrm{l}^{-1}$ (Johnson et al., 1981). Testicular volume was again calculated using precise measurements on the removed testis. After fixation, the epididymis was separated from the testis and both organs weighed separately. Daily sperm production was estimated using homogenizationhaemocytometric techniques (Amann, 1970).

\section{Testicular histology}

Small blocks of testicular tissues were fixed in Bouin's solution for $24 \mathrm{~h}$ and then transferred to $70 \%(\mathrm{v} / \mathrm{v})$ ethanol. The tissues were embedded in paraffin wax and sections, $7 \mu \mathrm{m}$ thick, were cut and stained with haematoxylin and eosin. The presence of seminiferous tubules, exhibiting complete spermatogenesis at the time of biopsy or castration, was verified under a microscope.

\section{Statistical analysis}

Data for characteristics involving repeated observations over time were analysed by analysis of variance for repeated measures. Other variables were analysed using factorial analysis of variance. Appropriate transformations of the data were performed whenever necessary. Differences were then tested by Duncan's new multiple-range test (Steel and Torrie, 1980).

\section{Results}

\section{Antibody titres and specificity}

In the control animals, the percentage binding of oestradiol in plasma diluted $1: 100$ was negligible $(<4 \%)$ throughout the experiment. In lambs immunized against oestrogen, between 16 and 20 weeks of age, mean percentage binding of oestradiol in plasma diluted 1:100 increased from $8.7 \pm 3.0 \%$ to $60.7 \pm 6.8 \%$. Between 22 and 30 weeks of age, mean percentage oestradiol binding in plasma diluted 1:5000 varied between $43.5 \pm 6.1$ and $57.1 \pm 5.6 \%$. Before the booster injection, antibody titres in plasma from all immunized lambs were less than 1:100, whereas, at the end of the experiment, mean antibody titre reached 1:8375 \pm 2654 (range 1:2000-1:10 000). At 30 weeks of age, antisera from each immunized lamb demonstrated very low crossreactivity towards testosterone, dihydrotestosterone and androstenedione $(<2.5 \%$ at $1000 \mathrm{pg}$ 


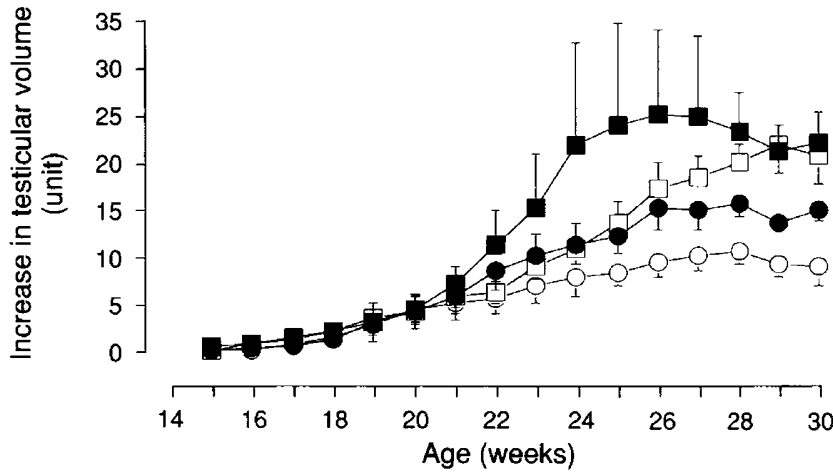

Fig. 1. Fold increase in testicular volume (unit \pm SEM) in relation to testicular volume at 14 weeks of age, in ram lambs immunized against BSA or against oestradiol-6-BSA, some of which underwent testicular biopsy. ( $\square$ ) Control, no biopsy $(n=5)$; ( $\bigcirc$ ) control, biopsy $(n=4)$; (ם) oestradiol-immunized, no biopsy $(n=4)$ and (O) oestradiolimmunized, biopsy $(n=4)$.

$\mathrm{ml}^{-1}$ ). The crossreactivities of the antisera towards oestrone and oestrone sulfate averaged $15.0 \pm 3.1 \%$ and $3.2 \pm 0.5 \%$, respectively.

\section{Live mass and testicular volume}

Mean live masses at 14 weeks of age were: control, no biopsy: $20.1 \pm 1.2 \mathrm{~kg}$; control, biopsy: $22.6 \pm 0.3 \mathrm{~kg}$; immunized, no biopsy: $19.7 \pm 1.5$; and immunized, biopsy: $23.0 \pm 0.2 \mathrm{~kg}$. Live mass increased progressively until the end of the experiment in all groups of lambs. The immunization treatment did not affect total live mass gain over the 16 week study (controls: $20.48 \pm 0.89 \mathrm{~kg}$ and oestradiol-immunized $20.45 \pm 1.15 \mathrm{~kg}$ ). In the four groups of lambs, the increase in testicular volume (Fig. 1) was small until 20 weeks of age, thereafter a period of rapid increase was observed until 26 weeks of age. From 27 weeks of age until the end of the experiment, except for the control lambs that were not biopsied, the increase in testicular volume reached a plateau and even regressed. Between 22 and 26 weeks of age, the increase in testicular volume was greater in the immunized lambs that were not biopsied than in the other groups; however, the differences between means were not statistically significant at any age. Immunization alone did not affect testicular volume. Biopsy treatment and interaction between immunization and age tended to affect this variable, although the effects were not statistically significant. In half of the lambs in each group, testicular volume decreased towards the end of the experiment. Testicular volumes of the lamb in each group that exhibited the most pronounced decline in testicular volume towards the end of the experiment is shown (Fig. 2).

\section{Concentrations of hormones}

Testosterone concentration in plasma increased significantly with age in all lambs $(P<0.01)$ (Fig. 3a). Analysis of variance showed a significant immunization effect $(P<0.01)$. Testosterone concentrations were significantly higher in oestradiolimmunized lambs than in controls at 22, 26 and 30 weeks of age $(P<0.001)$. There was a significant interaction between biopsy treatment and age $(P<0.01)$. At 30 weeks of age, a significantly higher concentration of testosterone was found in the immunized lambs that had not undergone biopsy than in the immunized lambs that had undergone biopsy $(P<0.02)$. Testosterone concentrations were still comparable between both groups of control animals at that age.

Mean FSH concentrations were significantly affected by immunization $(P<0.001)$ (Fig. $3 b)$. In oestradiol-immunized lambs, mean FSH concentrations were significantly higher than those in controls at 22,26 and 30 weeks of age $(P<0.001)$. At 22 weeks of age (before any biopsy procedure) FSH concentrations were higher $(P<0.02)$ in immunized lambs not biopsied than in immunized lambs that underwent biopsy treatment; however, at 26 and 30 weeks of age, differences in mean values between these two groups were not statistically significant. Mean FSH concentrations were comparable between the two control groups at all ages. Age did not significantly affect mean FSH concentrations between 22 and 30 weeks of age.

Immunization treatment significantly affected plasma LH concentrations $(P<0.01)$ (Fig. 3c). Since no significant effects on LH concentration due to biopsy treatment, or due to an interaction between biopsy and age, were found, the results from all control lambs and all oestradiol-immunized lambs were pooled and the LH pulse characteristics within a $6 \mathrm{~h}$ sampling period at four different ages were compared (Table 1). In the oestradiol-immunized lambs, mean $\mathrm{LH}$ concentrations were significantly higher at 22,26 and 30 weeks of age $(P<0.05)$. Mean pulse amplitude was the only LH pulse characteristic that was significantly affected by immunization treatment $(P<0.01)$. Mean pulse amplitude was significantly higher in immunized lambs at 26 weeks of age than in controls $(P<0.02)$. Mean pulse interval tended to be reduced in the immunized lambs compared with controls; however, this was not statistically significant. The number of LH peaks per $6 \mathrm{~h}$ sampling period, mean pulse amplitude, and mean pulse nadir were significantly affected by age $(P<0.02$, in all cases), but mean LH concentration was not affected. In all ram lambs, an increase in pulse frequency between 22 and 26 weeks of age was observed, as well as an increase in pulse nadir and a decrease in pulse amplitude throughout the study.

Mean prolactin concentrations in plasma were not affected by immunization or biopsy treatment. Prolactin concentrations in plasma were lower at 14 weeks of age (138.4 $\pm 18.8 \mathrm{ng}$ $\left.\mathrm{ml}^{-1}\right)$ than at any other age in all groups $(255.2 \pm 12.9 \mathrm{ng}$ $\mathrm{ml}^{-1}$ ). Between 22 and 30 weeks of age, there was no significant age effect.

\section{Total testicular blood plasma flow, testosterone production and response to $h C G$ challenge}

Blood flow was successfully measured in five testes from three control lambs and five testes from three oestradiol immunized lambs, none of which underwent biopsies. Total testicular blood plasma flow per testis $\left(\mathrm{ml} \mathrm{min}^{-1}\right.$ ) (Fig. 4a) and total testicular blood plasma flow per unit mass of testis $\left(\mu \mathrm{g}^{-1} \mathrm{~min}^{-1}\right.$ ) (Fig. 4b) were not significantly affected by the hCG challenge. Analysis of variance did not show a significant 

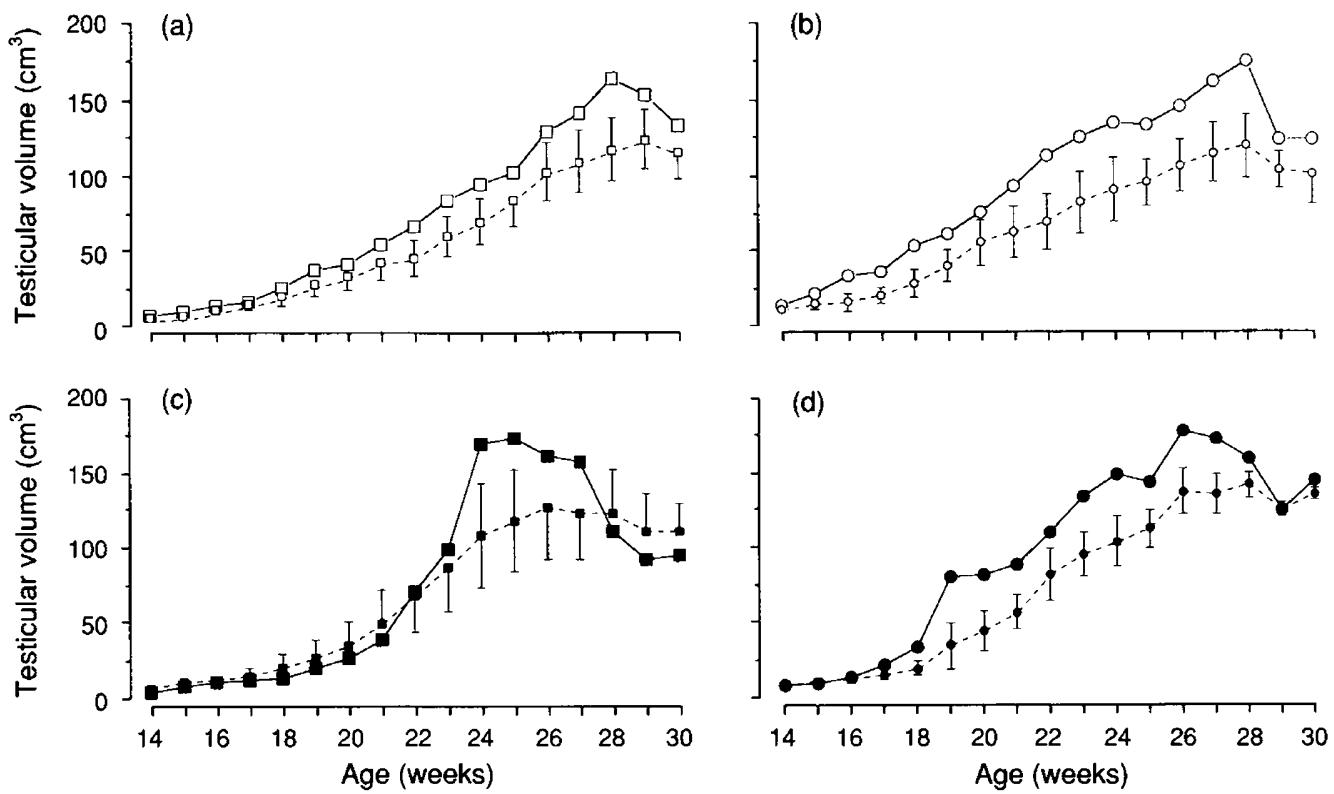

Fig. 2. Changes in testicular volume $\left(\mathrm{cm}^{3}\right)$ from 14 to 30 weeks of age in the ram lamb that exhibited the most pronounced decline in testicular volume towards the end of the experiment in each treatment group. The lambs were immunized against BSA or against oestradiol-6-BSA and some underwent testicular biopsy. (a) Control, no biopsy; (b) control, biopsy; (c) oestradiol-immunized, no biopsy and (d) oestradiol-immunized, biopsy. Mean testicular volume $\left(\mathrm{cm}^{3} \pm \mathrm{SEM}\right)$ for the corresponding group is represented by the dashed line.

Table 1. LH pulse characteristics in control $(n=9)$ and oestradiol-immunized $(n=8)$ ram lambs* at various ages

\begin{tabular}{lccccc}
\hline Treatment & $\begin{array}{c}\text { Mean LH concentration } \\
\left(\mu \mathrm{g} \mathrm{I}^{-1}\right)\end{array}$ & $\begin{array}{c}\text { Number of } \\
\text { peaks in } 6 \mathrm{~h}\end{array}$ & $\begin{array}{c}\text { Pulse interval } \\
(\mathrm{min})\end{array}$ & $\begin{array}{c}\text { Pulse amplitude } \\
\left.(\mu \mathrm{g} \mathrm{l})^{-1}\right)\end{array}$ & $\begin{array}{c}\text { Pulse nadir } \\
\left(\mu \mathrm{g} \mathrm{I}^{-1}\right)\end{array}$ \\
\hline Control & & & & & \\
$\quad 14$ weeks & $1.00 \pm 0.23$ & $1.9 \pm 0.3$ & $188.1 \pm 47.7$ & $4.26 \pm 1.45$ & $0.39 \pm 0.10$ \\
22 weeks & $0.75 \pm 0.14$ & $2.7 \pm 0.6$ & $172.9 \pm 40.7$ & $1.86 \pm 0.27$ & $0.44 \pm 0.14$ \\
26 weeks & $0.54 \pm 0.17$ & $2.4 \pm 0.7$ & $194.7 \pm 47.1$ & $0.90 \pm 0.15$ & $0.80 \pm 0.09$ \\
30 weeks & $0.70 \pm 0.22$ & $1.8 \pm 0.5$ & $242.8 \pm 46.7$ & $1.03 \pm 0.25$ & $0.96 \pm 0.19$ \\
Oestradiol-immunized & & & & & \\
14 weeks & $0.75 \pm 0.15$ & $2.3 \pm 0.3$ & $155.0 \pm 31.7$ & $3.10 \pm 0.69$ & $0.33 \pm 0.08$ \\
22 weeks & $1.30 \pm 0.10^{\mathrm{a}}$ & $3.5 \pm 0.5$ & $109.7 \pm 15.8$ & $2.42 \pm 0.32$ & $0.67 \pm 0.12$ \\
26 weeks & $1.12 \pm 0.07^{\mathrm{a}}$ & $3.0 \pm 0.3$ & $95.4 \pm 11.4$ & $1.60 \pm 0.14^{\mathrm{a}}$ & $1.07 \pm 0.03$ \\
30 weeks & $1.16 \pm 0.20^{\mathrm{a}}$ & $2.9 \pm 0.4$ & $145.0 \pm 37.6$ & $1.40 \pm 0.18$ & $1.02 \pm 0.07$ \\
\hline
\end{tabular}

* Blood was sampled every $20 \mathrm{~min}$ for $6 \mathrm{~h}$ on each occasion.

Values are means \pm SEM.

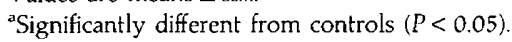

immunization effect on total testicular blood plasma flow per testis; however, a significant immunization effect was found when this variable was expressed per unit mass of testis $(P<0.01)$. For both variables, there was a significant interaction between immunization and time $(P<0.01)$.

Testosterone production per testis was significantly affected by immunization $(P<0.05)$ and by the hCG challenge $(P<0.001)$. Before stimulation with hCG, testosterone production per testis and testosterone concentration in jugular plasma tended to be higher in oestradiol-immunized, not biopsied lambs than in control, not biopsied lambs but the differences in means were not statistically significant (Table 2). After the
hCG injection, these variables were significantly higher in immunized lambs than in control lambs $(P<0.05$, for both).

Testis plus epididymis mass, testicular volume and daily sperm production at castration

Testicular volume at castration was significantly affected by biopsy $(P<0.03)$. Immunization tended to increase this variable; however, this effect was not statistically significant. Interaction between biopsy and immunization was not significant. Testicular volume was significantly smaller in control 

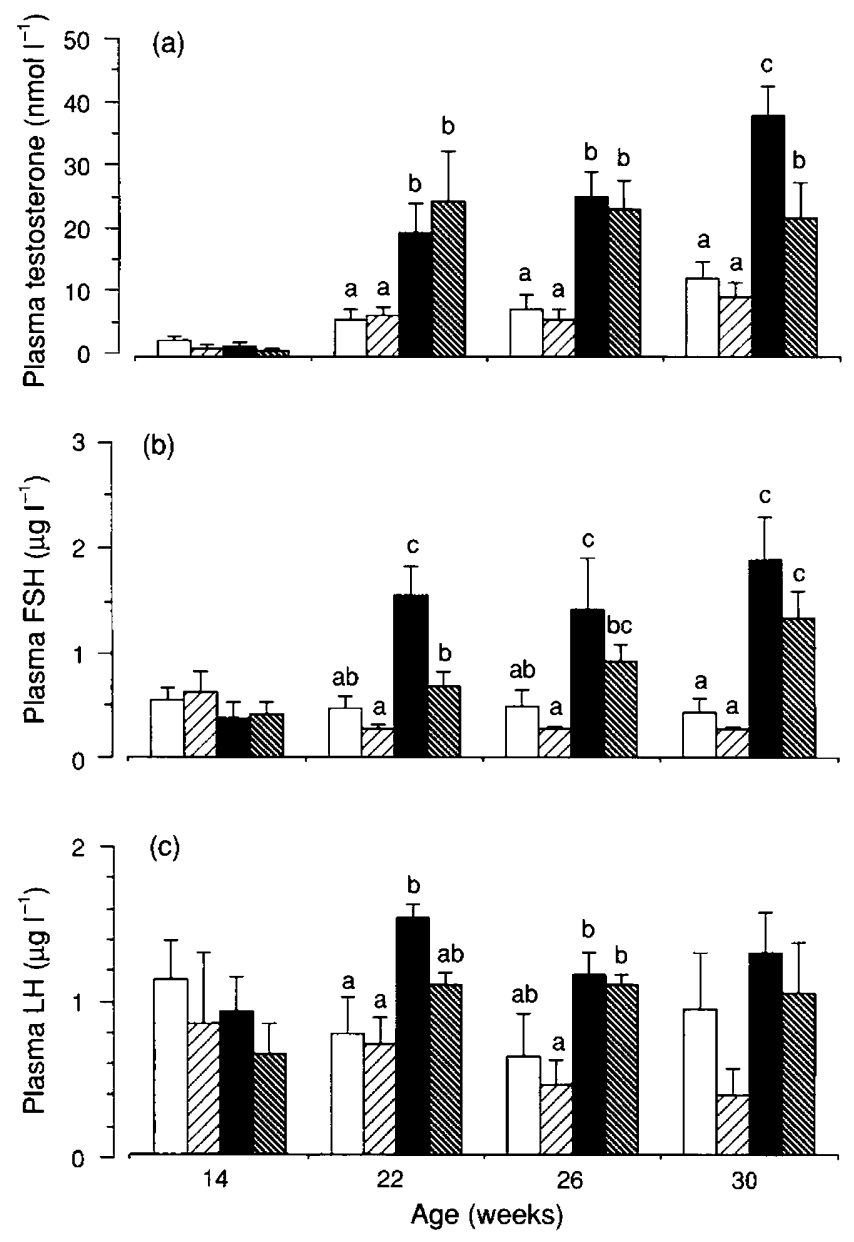

Fig. 3. Mean hormonal concentration $( \pm$ SEM) in jugular venous plasma for (a) testosterone (nmol l-1), (b) FSH ( $\mu \mathrm{g} \mathrm{l}^{-1}$ ) and (c) $\mathrm{LH}$ $\left(\mu \mathrm{g} \mathrm{l}^{-1}\right)$ at various ages in ram lambs immunized against BSA or against oestradiol-6-BSA, some of which underwent testicular biopsy. ( $\square$ ) control, no biopsy $(n=5)$; (包) control, biopsy $(n=4)$; ( oestradiol-immunized, no biopsy $(n=4)$ and $(\mathbb{\mathbb { N }})$ oestradiolimmunized, biopsy $(n=4)$. Values with different superscripts are significantly different $(P<0.05)$.

lambs that underwent biopsy $(P<0.05)$ than in control and immunized lambs that had not, although the larger lambs were used for biopsy (Fig. 5a). Analysis of variance did not show any significant immunization or biopsy effect on testis mass, epididymis mass or testis plus epididymis mass and there was no significant interaction between immunization and biopsy, in any case (Fig. 5a). Immunization or biopsy treatment did not significantly affect daily sperm production per testis or per unit mass of testis (Fig. 5b). Again, for each of these two variables, there was no significant interaction between immunization and biopsy treatment. The minimum daily sperm production value $\left(7.0 \times 10^{5}\right.$ spermatozoa $g^{-1}$ testis) was found in an oestradiol immunized lamb that had not undergone biopsy; this lamb had exhibited the most pronounced decline in testicular volume towards the end of the experiment (see Fig. 2c). The maximum daily sperm production value $\left(4.9 \times 10^{7}\right.$ spermatozoa $\mathrm{g}^{-1}$ testis) was found in a control lamb that had not undergone biopsy.
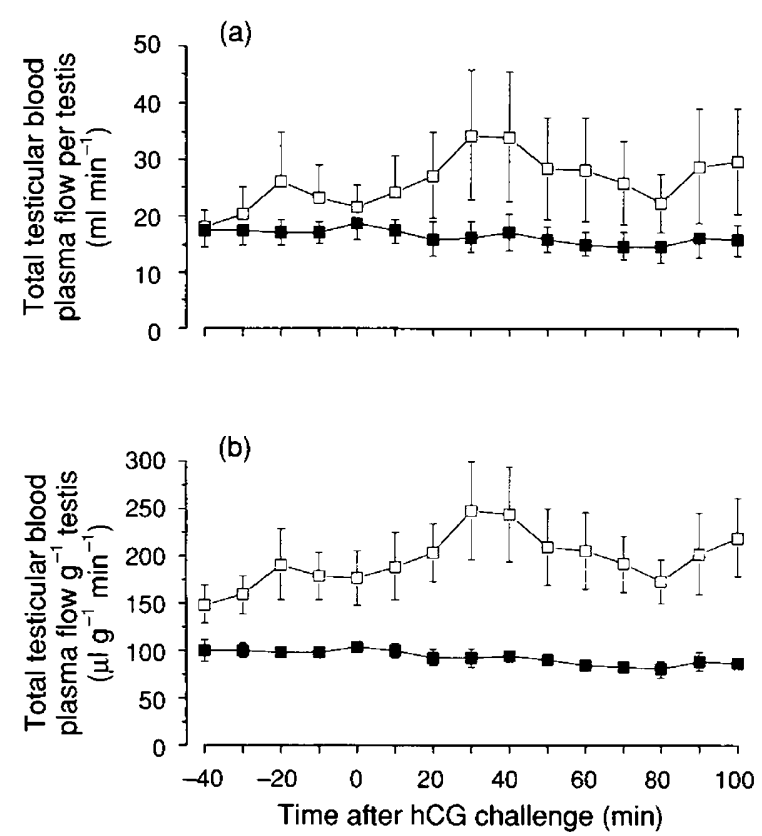

Fig. 4. Total testicular blood plasma flow (a) per testis $\left(\mathrm{ml} \mathrm{min}^{-1}\right.$ ) and (b) per unit mass of testis $\left(\mu \mathrm{I} \mathrm{g}^{-1} \mathrm{~min}^{-1}\right)$, before and after an hCG injection (20 $\mathrm{iu} \mathrm{kg}^{-1}$ body mass), in ram lambs immunized against (\lrcorner$)$ BSA or against ( $)$ oestradiol- $6-$ BSA. No animals underwent testicular biopsy. Values are means $\pm \operatorname{SEM}$ ( $n=$ five testes from three lambs in each group).

\section{Testicular histology and spermatogenesis}

At 22 weeks of age, three of four control lambs and two of four oestradiol-immunized lambs, all of which had undergone biopsies, had spermatozoa present in the lumen of the seminiferous tubules. At 26 weeks of age, all immunized and all control lambs that had undergone biopsies had achieved puberty. By the end of the experiment, spermatozoa were present in the testes of all lambs. At 22 and 26 weeks of age, large vacuoles were observed in the epithelium of the seminiferous tubules of one biopsied, immunized lamb. At 30 weeks of age, one lamb (immunized, not biopsied) showed few germ cells, with other apparent signs of degeneration in the seminiferous tubules such as those observed in another lamb at 22,26 and 30 weeks of age. In the other lambs, the general aspect of the seminiferous tubules appeared normal and contained numerous meiotic figures and apparently normal spermiogenesis with round or elongated spermatids at 30 weeks of age.

\section{Discussion}

To our knowledge, this is the first time that active immunization against oestradiol has been used to study pubertal development in ram lambs. The main advantage of active immunization is that it involves continuous production of antibodies that are always likely to be in excess of endogenous antigen production (Nieschlag and Wickings, 1978). In the experiment reported here, we showed that prepubertal Merino ram lambs responded well to the immunization procedure used 
Table 2. Mean testosterone concentration in jugular vein and testosterone production per testis, before and after an hCG injection (20 iu $\mathrm{kg}^{-1}$ body mass), in rams lambs immunized against BSA (control, no biopsy) or against oestradiol-6-BSA (oestradiol-immunized, no biopsy)

\begin{tabular}{lccc}
\hline Treatment & Time & $\begin{array}{c}\text { Testosterone concentration }{ }^{*} \\
\left(\mathrm{nmol} \mathrm{l}^{-1} \text { ) }\right.\end{array}$ & $\begin{array}{r}\text { Testosterone production } \\
\text { (nmol min }\end{array}$ \\
\hline Control, no biopsy & Before hCG & $3.0 \pm 0.3^{\mathrm{a}}$ & $1.82 \pm 0.90^{\mathrm{d}}$ \\
Control, no biopsy & After hCG & $56.0 \pm 3.0^{\mathrm{b}}$ & $17.56 \pm 7.24^{\mathrm{e}}$ \\
Oestradiol-immunized, no biopsy & Before hCG & $24.6 \pm 16.3^{\mathrm{a}}$ & $5.21 \pm 2.38^{\mathrm{d}}$ \\
Oestradiol-immunized, no biopsy & After hCG & $246.3 \pm 64.6^{\mathrm{c}}$ & $52.51 \pm 11.31^{\mathrm{f}}$ \\
\hline
\end{tabular}

Values are means \pm SEM.

*Three animals per group; ${ }^{\dagger}$ five testes per group.

Values with different superscripts are significantly different $(P<0.05)$.
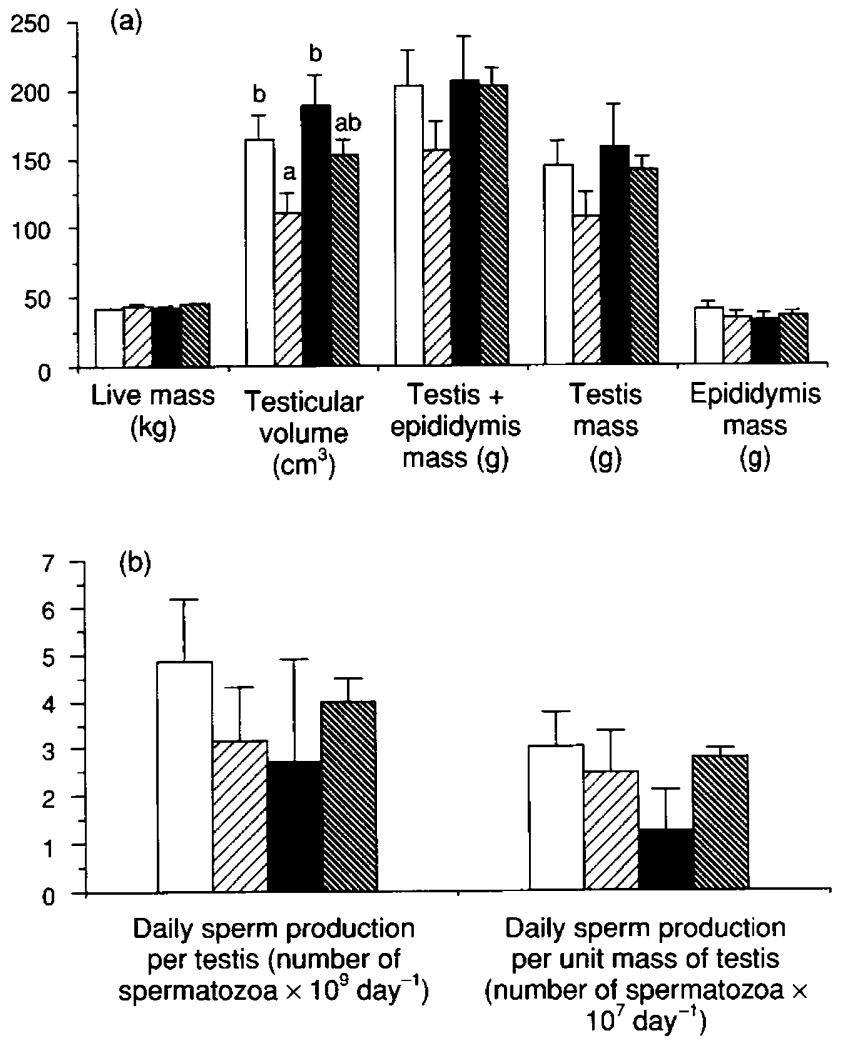

Fig. 5. (a) Mean values ( \pm SEM) for different variables measured at time of castration and (b) daily sperm production (number of spermatozoa) per testis $\left(\times 10^{9}\right)$ and per unit mass of testis $\left(\times 10^{7}\right)$ in ram lambs immunized against BSA or against oestradiol-6-BSA, some of which underwent testicular biopsy. ( $\square$ ) Control, no biopsy $(n=5)$;

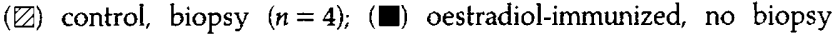
$(n=4)$ and $(\mathbb{Q})$ oestradiol-immunized, biopsy $(n=4)$. Values with different superscripts are significantly different $(P<0.05)$.

and produced a considerable amount of oestradiol antibodies. Our results do not support the hypothesis that puberty in ram lambs can be advanced by active immunization against oestradiol.

Pubertal development in the rams used in this study was characterized by increases in LH pulse frequency, $\mathrm{LH}$ pulse nadir, plasma testosterone concentrations, testicular volume and by a decrease in LH pulse amplitude. Similar maturational changes have been described for rams by Olster and Foster (1986). A significant increase in plasma gonadotrophin concentrations, which was accompanied by a significant increase in plasma testosterone concentrations, was observed in lambs immunized against oestrogen. The fact that LH pulse interval was reduced and that $\mathrm{LH}$ pulse amplitude increased significantly in the oestradiol-immunized ram lambs compared with controls, supports the view that the hypothalamus and the pituitary are important sites for oestradiol action (Thiéry and Martin, 1991). The increase in FSH concentrations in the oestradiol-immunized rams also supports the view that this pituitary hormone is, in part, regulated by oestrogens during pubertal development. In male sheep, oestradiol and inhibin appear to regulate FSH secretion (Price, 1991). Simultaneous increases in FSH and testosterone secretion have frequently been observed in oestradiol-immunized, adult rams (Schanbacher, 1979; Sanford, 1987b; Schanbacher et al., 1987; Monet-Kuntz et al., 1988). Similarly, in adult rams, immunoneutralization of circulating oestradiol had led to an increase in plasma LH concentrations (Schanbacher, 1979, 1984; Sanford, 1985, 1987b; Schanbacher et al., 1987; Monet-Kuntz et al., 1988). The fact that high concentrations of testosterone in plasma did not reduce gonadotrophin secretion in the immunized ram lambs, even after 16 weeks of immunization, suggests that the negative feedback system regulating the hypothalamic-pituitary axis has lost its efficiency or that peripheral oestradiol is required for optimal functioning of this regulatory system.

The increase in gonadotrophin and testosterone secretion observed in the oestradiol-immunized ram lambs seemed to confer no reproductive advantages. At the end of the study, the spermatogenic function was comparable between control and immunized ram lambs. The steroidogenic function of the testes of the immunized lambs was markedly enhanced; thus, it seems unlikely that all the circulating testosterone was unavailable to target cells because of the presence of oestradiol antibodies. Androgen binding was shown to be negligible in vitro; even high concentrations of non-labelled testosterone, dihydrotestosterone or androstenedione $\left(1000 \mathrm{pg} \mathrm{ml}^{-1}\right)$ did not displace labelled oestradiol from the antibodies in diluted plasma. In addition, metabolic clearance rate of testosterone (related to the unbound form of testosterone) is unaffected by 
active immunization against oestradiol in rats (Nishihara and Takahashi, 1983) and in rams (Schanbacher et al., 1987), suggesting that the oestradiol antibodies do not interfere with the metabolism and activities of testosterone. The differences between the results presented here and those obtained by Land et al. (1981) may be due partly to the magnitude of the endocrine changes subsequent to neutralization of oestradiol. Land et al. (1981) observed an increase in testicular growth, without significant changes in LH, FSH or testosterone concentrations (measured at 18 weeks of age), in Merino lambs that received $5 \mathrm{ml}$ of anti-oestradiol antiserum at 14,16 and 18 weeks of age (that is, at a much lower titre than in the present study). Other factors should also explain some of the differences between the results obtained in these two studies, for example different sensitivity of the rams to oestrogen, the degree to which oestradiol was neutralized, photoperiod, nutrition and immunization factors.

One of the most striking observations in the present work is the decline in testicular volume observed towards the end of the study, in about half of the lambs. This decline was more pronounced in the oestradiol-immunized lambs, particularly in two lambs in which major defects in spermatogenesis were observed. These testicular abnormalities were also reflected by the very low daily sperm production in one lamb and, by the significantly lower testicular blood flow found at the end of the experiment in other immunized lambs that did not undergo biopsies. This last observation contrasts with that made by other investigators who reported a larger volume of blood and lymphatic vessels within the testis interstitium in oestradiolimmunized rams (Monet-Kuntz et al., 1988), and a higher percentage volume of blood vessels in the testes of oestradiol immunized rabbits (Nieschlag et al., 1975). It is unclear whether the hormonal changes that occurred after immunization against oestradiol were responsible for the change in testicular blood flow. A decrease in testicular blood flow in response to a long-term increase in gonadotrophin secretion following immunoneutralization of testosterone in adult rams was observed (Auclair et al., 1995). It is perhaps relevant that testis blood flow is lower in surgically hypophysectomized rams treated with high doses of pituitary extract, sufficient to produce LH and FSH concentrations about five times higher than in intact controls (Setchell ef al., 1991a). The present data and data obtained in testosterone-immunized rams (Auclair et al., 1995) clearly show that testicular blood flow is unaffected, in the short term, by a single hCG injection. This lack of immediate response of testis blood flow to hCG is similar to the situation in rats, although, in rats, there is initially a fall and then an increase in testicular blood flow after hCG injection (see Setchell, 1990, for review). Since a reduction in testicular blood flow would impose an upper limit on the amount of steroid being released into the circulation (Setchell 1986; Setchell et al., 1991b), such a mechanism could play an important role in rams, immunized against gonadal steroid, in reducing the amount of gonadotrophins that reach Leydig cells. More work is required to determine exactly how reproductive hormones control this blood flow limitation process and whether a reduction in bioavailability of oestradiol has direct effects on testicular blood flow (Setchell 1986, 1990), vascular permeability (Sowerbutts et al., 1986) and vascular smooth muscle tone (Walsh, 1994). What effect reduced blood flow has on testicular development is not yet known, but severe alteration of the spermatogenic function, such as that observed in some of the oestradiol-immunized lambs would certainly influence this variable. It is generally accepted that the amount of blood flowing through the testis is determined largely by the mass of the tubules (Setchell et al., 1991b).

It is not known whether the high concentration of testosterone produced in the oestradiol-immunized lambs contributed to the decline in testicular volume observed towards the end of the experiment (for example, direct inhibitory effects on testicular function). However, Sanford (1987b) suggested that a considerable testosterone response to immunization could be detrimental to testicular function in the long term. Sanford (1987b) reported that, for the adult crossbred rams living in Canada under natural lighting, the testicular regression occurring in early winter was more apparent in rams that were passively immunized against oestradiol. The presence of intratesticular oestradiol, even in small amounts, may also be a requisite for the normal functioning of the testis. The recent finding that germ cells of mice express $\mathrm{P} 450$ aromatase activity suggests that oestrogen could participate in the autocrine or paracrine regulation of spermatogenesis (Nitta et al., 1993). Our results also support the view that oestrogens play such a role in the testes of developing lambs. Another possible explanation for the decline in testicular volume is that environmental conditions, perhaps the lighting regimen, were not suitable for optimal testicular development in these winter-born lambs never exposed to decreasing day length (Colas et al., 1987). The prolactin data indicate that the lambs interpreted the $12 \mathrm{~h}$ light: $12 \mathrm{~h}$ dark photoperiod as long days; this is in contrast to the autumn-born crossbred ram lambs, studied by Klindt $e t$ al. (1985), which interpreted the same artificial cycle as short days.

The high concentration of circulating testosterone observed in the oestradiol-immunized lambs did not have any positive effect on total live mass gain over the 16 week study period. It is possible that a particular amount of oestrogens might be required with testosterone to obtain a measurable anabolic effect and the continuous maturation of the testes in ram lambs. Nevertheless, since there is no growth spurt during pubertal development in sheep, a relatively lower (or normal) testosterone concentration may already have maximal effect on body growth. Biopsy sampling did not significantly impair testicular development or daily sperm production. Successful repetitive testicular biopsies have already been reported in rams during pubertal development (Lunstra and Echternkamp, 1988) and in adult bulls (Pimentel et al., 1984). A procedure that minimizes damage to the vascular layer of the tunica albuginea and minimizes postoperative inflammation appear to be the key to successful biopsies. Nevertheless, we cannot conclude that this procedure is totally without consequences, as a reduction in testicular volume (precisely measured at castration) in control lambs, in which biopsies had been taken, was observed, as well as a reduction in plasma testosterone concentration in oestradiol-immunized lambs submitted to biopsy sampling. These observations suggest that the use of this surgical procedure in an endocrinological study on pubertal development should be avoided.

In conclusion, this study has provided additional evidence that oestradiol in the blood circulation plays an important role in the regulation of $\mathrm{LH}_{\mathrm{i}}$ and $\mathrm{FSH}_{\mathrm{S}}$ secretion in ram dambs during 
pubertal development. Moreover, it has been shown that active immunization against oestradiol in ram lambs does not advance puberty and does not confer any reproductive or maturational advantages.

The authors are grateful to R. I. Cox (Hormone Assay Development Group, CSIRO, Division of Animal Production, Prospect, NSW, Australia) and to the National Institute of Diabetes, Digestive and Kidney Diseases (Torrance, CA) for generous supplies of radioimmunoassay materials. This work was supported by grants from the Australian Wool Corporation and the 'Fonds pour la Formation de Chercheurs et l'Aide à la Recherche' (Québec, Canada).

\section{References}

Amann RP (1970) Sperm production rates. In The Testis vol. I pp 433-482 Eds AD Johnson, WR Gomes and NL Vandemark. Academic Press, London

Aquilano DR and Dufau ML (1983) Changes in ribonucleic acid polymerase activities in gonadotropin-treated Leydig cells: an oestradiol-mediated process Endocrinology 113 94-103

Auclair D, Sowerbutts SF and Setchell BP (1995) Effect of active immunization against testosterone in adult rams on plasma gonadotrophin concentrations, spermatogenic function, testicular blood flow, epididymis mass and mating behaviour in adult rams Joumal of Reproduction and Fertility 104 17-26.

Brinkmann AO, Mulder E, Lamers-Stahlhofen GJM and van der Molen HJ (1972) An estradiol receptor in rat testis interstitial tissue FEBS Letters 26 301-305

Brinkmann AO, Leemborg FG, Roodnat EM, de Jong FH and van der Molen HJ (1980) A specific action of estradiol on enzymes involved in testicular steroidogenesis Biology of Reproduction 23 801-809

Chandrasekhar Y, Holland MK, D'Occhio MJ and Setchell BP (1985a) Spermatogenesis, seminal characteristics and reproductive hormone levels in mature rams with induced hypothyroidism and hyperthyroidism Journal of Endocrinology 105 39-46

Chandrasekhar Y, D'Occhio MJ, Holland MK and Setchell BP (1985b) Activity of the hypothalamo-pituitary axis and testicular development in prepubertal ram lambs with induced hypothyroidism or hyperthyroidism Endocrinology 117 1645-1651

Colas G, Guerin Y, Briois M and Ortavant R (1987) Photoperiodic control of testicular growth in the ram lamb Animal Reproduction Science 13 255-262

Daehlin L, Thore J, Bergman B, Damber JE and Selstam G (1985) Direct inhibitory effects of natural and synthetic oestrogens in testosterone release from human testicular tissue in vitro Scandinavian Journal of Urology and Nephrology 19 7-12

de Boer W, Mulder E and van der Molen HJ (1976) Effects of oestradiol-17 $\beta$, hypophysectomy and age on cytoplasmic oestradiol- $17 \beta$ receptors sites in rat testis interstitial tissue Journal of Endocrinology 70 397-407

D'Occhio MJ and Brooks DE (1983) Seasonal changes in plasma testosterone concentration and mating activity in Border Leicester, Poll Dorset, Romney and Suffolk rams Australian Journal of Experimental Agriculture and Animal Husbandry 23 248-253

D'Occhio MJ and Setchell BP (1984) Pituitary and testicular responses in sexually mature bulls after intravenous injections of graded doses of LH-releasing hormone Journal of Endocrinology 103 371-376

Hsueh AJW, Dufau ML and Catt KJ (1978) Direct inhibitory effect of estrogen on Leydig cell function of hypophysectomized rats Endocrinology 103 1096-1102

Jenkins N, Knight PG, Howles CM, Morris BA and Waites GMH (1986) Effects of passive immunization against oestradiol-17 $\beta$ on some endocrine values of the male lamb Journal of Reproduction and Fertility 78 281-286

Johnson L, Petty CS and Neaves WB (1981) A new approach to quantification of spermatogenesis and its application to germinal cell attrition during human spermiogenesis Biology of Reproduction 25 217-226

Kaland N and MacArthur CS (1950) Determination of sodium thiosulphate and para-amino-hippuric acid in renal clearance tests Journal of Laboratory and Clinical Medicine 35 836-841

Kalla NR, Nisula BC, Menard R and Loriaux DL (1980) The effect of estradiol on testicular testosterone biosynthesis Endocrinology 106 35-39

Klindt J, Ohlson DL, Davis SL and Schanbacher BD (1985) Ontogeny of growth hormone, prolactin, luteinizing hormone, and testosterone secretory patterns in the ram Biology of Reproduction 33 436-444
Land RB, Baird DT and Carr WR (1981) Increased testicular growth of Tasmanian Merino ram lambs treated with antisera to oestrogens journal of Reproduction and Fertility 62 151-158

Laurie MS and Setchell BP (1978) The continuous measurement of testicular blood flow in the ram, in relation to the pulsatile secretion of testosterone Joumal of Physiology $28710 \mathrm{P}$

Lunstra DD and Echternkamp SE (1988) Repetitive testicular biopsy in the ram during pubertal development Theriogenology 29 803-810

Martin GB, Taylor PL and McNeilly AS (1987) Effect of small doses of bovine follicular fluid on the tonic secretion of gonadotrophins in the ewe Journal of Endocrinology $11473-79$

Mieusset R, Sowerbutts SF, Zupp JL and Setchell BP (1992) Increased flow of testicular blood plasma during local heating of the testes of rams Journal of Reproduction and Fertility 94 345-352

Moger WH (1980) Direct effects of estrogens on the endocrine function of the mammalian testis Canadian Journal of Physiology and Pharmacology 58 1011-1022

Monet-Kuntz C, Hochereau-de-Reviers MT, Pisselet C, Perreau C, Fontaine I and Schanbacher BD (1988) Endocrine parameters, hormone receptors, and functions of the testicular interstitium and seminiferous epithelium in estradiol-immunized Ile-de-France rams Joumal of Andrology 9 278-283

Mulder E, Van Beurden-Lamers WMO, Brinkmann AO, Mechielsen MJ and van der Molen HJ (1974) High affinity binding of oestradiol by rat testis interstitial tissue and by several other tissues of the male rat Journal of Steroid Biochemistry 5 955-959

Nieschlag E and Wickings EJ (1978) Biological effects of antibodies to gonadal steroids Vitamins and Hormones 36 165-202

Nieschlag E, Usadel KH, Wickings EJ, Kley HK and Wuttke W (1975) Effects of active immunization with steroids on endocrine and reproductive functions in male animals. In Immunization with Hormones in Reproductive Research pp 154-172 Ed. E Nieschlag. North Holland Publishing Co., Amsterdam

Nishihara M and Takahashi M (1983) Effects of active immunization against estradiol-17 $\beta$ on luteinizing hormone and testosterone in male rats Biology of Reproduction 29 1092-1097

Nitta H, Bunick D, Hess RA, Janulis L, Newton SC, Millette CF, Osawa Y, Shizuta Y, Toda K and Bahr JM (1993) Germ cells of the mouse testis express P450 aromatase Endocrinology 132 1396-1401

Olster DH and Foster DL (1986) Control of gonadotropin secretion in the male during puberty: a decrease in response to steroid inhibitory feedback in the absence of an increase in steroid-independent drive in the sheep Endocrinology 118 2225-2234

Olster DH and Foster DL (1988) Control of gonadotrophin secretion during the pubertal and seasonal transitions in the male sheep Journal of Reproduction and Fertility 82 179-191

Pelletier J (1982) Hypothalamic and pituitary cytosol receptors to 5- $\alpha$ dihydrotestosterone and oestradiol $17 \beta$ during the prepubertal period in the male lamb Acta Endocrinologica 100 161-167

Pelletier J and Caraty A (1981) Characterization of cytosolic 5 $\alpha$-DHT and $17 \beta$-estradiol receptors in the ram hypothalamus journal of Steroid Biochemistry 14 603-611

Pimentel CA, Santos PFM, Ribeiro WNL, Schuch LH and Machado AA (1984) Clinical and histopathological validation of testicular biopsy in bulls Proceedings of the 10th International Congress in Animal Reproduction and Artificial Insemination (University of Illinois, USA) HI 276 (Abstract)

Price CA (1991) The control of FSH secretion in the larger domestic species Journal of Endocrinology 131 177-184

Ramirez VD (1973) Endocrinology of puberty. In Handbook of Physiology, Endocrinology II, Part 1 pp I-28 Eds RO Greep and EB Astwood. American Physiological Society, Washington DC

Ronco AM, Pino AM and Valladares LE (1988) RNA synthesis in the Leydig cells of the mature rat: effect of oestradiol-17ß Journal of Endocrinology 116 387-392

Sanford LM (1985) Evidence that estrogen regulation of testosterone secretion in adult rams is mediated by both indirect (gonadotropin dependent) and direct (gonadotropin independent) means Journal of Andrology 6 306-314

Sanford LM (1987a) Luteinizing hormone release in intact and castrate rams is altered with immunoneutralization of endogenous estradiol Canadian Journal of Physiology and Pharmacology 65 1442-1447

Sanford LM (1987b) Seasonal variation in circulating gonadotropin and testosterone levels and in testis size of yearling rams during, and subsequent to, immunoneutralization of estradiol or tamoxifen treatment in the nonbreeding season Canadian Journal of Animal Science 67 391-404 
Schanbacher BD (1979) The regulation of FSH secretion in rams Journal of Reproduction and Fertility Supplement 26 15-16

Schanbacher BD (1984) Regulation of luteinizing hormone secretion in male sheep by endogenous estrogen Endocrinology 115 944-950

Schanbacher BD, Winters SJ, Rehm T and D'Occhio MJ (1984) Pituitary androgen receptors and the resistance of long-term castrated rams to the androgenic control of luteinizing hormone (LH) secretion Journal of Steroid Biochemistry 20 1227-1232

Schanbacher BD, Pelletier J and Hochereau-de-Reviers MT (1987) Follicle stimulating hormone, luteinizing hormone and testicular Leydig cell responses to estradiol immunization in Ile-de-France rams journal of Andrology 8 97-102

Setchell BP The movement of fluids and substances in the testis Australian Journal of Biological Sciences 39 192-207

Setchell BP (1990) Local control of testicular fluids Reproduction, Fertility and Development 2 291-309

Setchell BP and Waites GMH (1964) Blood flow and the uptake of glucose and oxygen in the testis and epididymis of the ram Journal of Physiology 171 $411-425$

Setchell BP, Locatelli A, Perreau C, Pisselet C, Fontaine I, Kuntz C, Saumande J, Fontaine J and Hochereau de Reviers MT (1991a) The form and function of the Leydig cells in hypophysectomized rams treated with pituitary extract when spermatogenesis is disrupted by heating the testes Journal of Endocrinology 131 101-112

Setchell BP, Auclair D, Maddocks S and Mieusset R (1991b) Perméabilité vasculaire et débit sanguin testiculaire Contraception, Fertilité, Sexualité 19 $725-732$
Sowerbutts S, Jarvis LG and Setchell BP (1986) The increase in testicular vascular permeability induced by human chorionic gonadotropin involves 5-hydroxytryptamine and possibly oestrogens but not testosterone, prostaglandins, histamine or bradykinin Australian Journal of Experimental, Biological and Medical Sciences 64137

Steel RGD and Torrie JH (1980) Principles and Procedures of Statistics: A Biometrical Approach 2nd Edn. McGraw-Hill Book Co., New York

Thiéry JC and Martin GB (1991) Neurophysiological control of the secretion of gonadotrophin-releasing hormone and luteinizing hormone in the sheep - a review Reproduction, Fertility and Development 3 137-173

Thieulant ML and Pelletier J (1979) Evidence for androgen and estrogen receptors in castrated ram pituitary cytosol: influence of time after castration Journal of Steroid Biochemistry 10 677-687

Thieulant ML and Pelletier J (1985) Oestradiol binding to nuclei of anterior cells of the ram Acta Endocrinologica 109 50-57

Tsai-Morris CH, Aquilano DR and Dufau ML (1985) Cellular localization of rat testicular aromatase activity during development Endocrinology 116 38-46

Van Beurden-Lamers WMO, Brinkmann AO, Mulder $E$ and van der Molen $\mathrm{HJ}$ (1974) High affinity binding of oestradiol-17 $\beta$ by cytosols from testis interstitial tissue, pituitary, adrenal, liver and accessory sex glands of the male rat Biochemical Journal 140 495-502

van der Molen HJ, Brinkmann AO, de Jong FH and Rommerts FFG (1981) Testicular oestrogens Joumal of Endocrinology 89 33P-46P

Walsh MP (1994) Regulation of vascular smooth muscle tone Canadian journal of Physiology and Pharmacology 72 912-936 